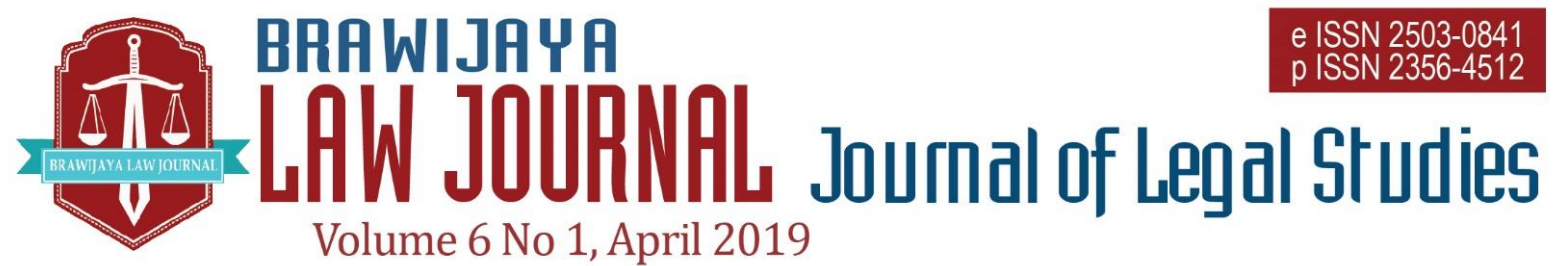

Nationally Accredited No. 30/E/KPT/2018 Dated 24th October 2018

This work is licensed under a Creative Commons Attribution-NonCommercial 4.0 International License

\title{
Discourse Interpretation of Public Policy in the Context of Enforcement of Foreign Arbitral Awards in Indonesia
}

\author{
AAA Nanda Saraswati ${ }^{a}$ \\ Choirul Hidayat ${ }^{b}$
}

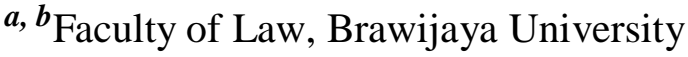

Email: anandasaraswati@ub.ac.id

Submitted : 2019-01-03 | Accepted : 2019-02-08

\begin{abstract}
The use of the concept of "public policy" by the national judiciary as a basis for the refusal of recognition and enforcement of foreign arbitral awards leaves an issue in the Indonesian judicial system. The main problem often questioned by the international community is that Indonesia refuses to enforce and even reject foreign arbitral awards on the grounds of violating public policy. This paper aims to analyze the interpretation of the concept of public policy used by judges as one of the reasons for the refusal of the recognition and enforcement of foreign arbitral awards and whether such interpretation is in accordance with international standards. The results shows that Indonesian courts tend to use a "domestic" approach when interpreting public policy namely as a provision and principles of law and national interests, rather than the international standard approach. Such approach have raised a number of critics from other countries. Not only because it is not in accordance with the values and principles of international law, but the interpretation is considered not to prioritize the purpose of the New York Convention, namely facilitating the recognition and enforcement of foreign arbitral awards.
\end{abstract}

Keywords: interpretation; public policy; recognition and enforcement; foreign arbitral awards.

\section{INTRODUCTION}

The main international convention on enforcement arbitral awards is of course the Convention on the Recognition and Enforcement of Foreign Arbitral Awards 1958 (hereinafter the 1958 New York

1 Indonesia is a party to the Convention on the Recognition and Enforcement of Foreign Arbitral Awards 1958 through accession dated on 7 October 1981
Convention). More than 150 states are members to the convention, including Indonesia. ${ }^{1}$ Related to public policy, the convention states that: ${ }^{2}$

Recognition and enforcement of an arbitral award may also be refused if the competent authority in the country

2 Convention of the Recognition and Enforcement of Foreign Arbitral Awards, 1958, article V (2) b 
where recognition and enforcement is sought finds that the recognition or enforcement of the award would be contrary to the public policy of that country."

Such article gives the courts of member states the right to refuse the recognition and enforcement of an arbitral award if such enforcement is contrary to the public policy of the state concerned. Until today, the concept of public policy remains a highly debated, controversial and complex subject since the notion was (intentionally) not defined in the Convention and its concrete manifestations may substantially vary from one state jurisdiction to another. Although over time, the laws and practice of arbitration have tried to align the public policy concept so that member states may benefit from a universally accepted concept, the difference approaches of national courts has made this task hard if not impossible.

This problem is also being faced by Indonesia. Despite being a party to the Convention, Indonesia has been accused of being unfriendly to foreign arbitral awards. This is due to the silence of the meaning or definition of public policy under the Indonesian arbitration law, making it subject to broad interpretations in various cases. This paper aims to analyze the interpretation of the concept of public policy used by Indonesian judges as one of the reasons for the refusal of the recognition and enforcement of foreign arbitral awards and whether such interpretation is in accordance with international standards.

Peter Marzuki, Penelitian Hukum (Prenada Media Group, Jakarta, 2005) 93

\section{LEGAL MATERIALS AND METHODS}

This paper is based on a normative research, namely the procedure of research based on legal scientific logic from the normative side which is focused on studying the application of the rules or norms in positive law. ${ }^{3}$

The approach used is the statute, the conceptual and the comparative approach. The statute approach is carried out by examining various positive legal provisions, especially international conventions and agreements related to international arbitration namely the New York Convention 1958. This is done to understand the content of the philosophy of the convention so that it can analyze whether there is a philosophical clash between the convention and the issues at hand. To support the study to be more comprehensive, a conceptual approach is used to study the views and legal doctrines, especially related to the concept of public order. Whereas a comparative approach is used to compare positive laws and jurisprudence in countries in order to analyze the similarities and differences that exist, to find the direction of regulation at the international level.

\section{RESULTES AND DISCUSSIONS}

\section{The Concept of Public Policy}

Public policy is one of the principles that must be considered important, especially in the scope of private international law. ${ }^{4}$ This principle is recognized in every legal system, both in common and civil law. In common law legal system, this principle is commonly known as public policy, while in civil law legal system it is known with the

4 Sudargo Gautama, Hukum Perdata Internasional Indonesia Buku IV (Penerbit Alumni, Bandung, 1989) 3 
term ordre public, one of which in France. Besides that, there are still many other terms on the principle of public order, such as openbare orde in Dutch, vorbehaltklausel in German, ordine publico in Italian, and orden publico in Spanish. ${ }^{5}$

In the study of Private International Law, there is yet a specific definition formulated for the term public policy (order). Until now there is no clear definition of what is meant by the principle. Many writers have tried to describe public policy, which only leads to conflicts of thoughts. Although there is no unity of opinion among legal experts, they all hold that public policy plays an important role in every state's legal system. This is inseparable to the fact that each country having its own general policy, where such notion is always dynamic and changes according to time. Another reason why public policy is difficult to define is because the level of fundamentality of moral conviction is determined differently for each case in various countries, according to its conditions and situations. ${ }^{6}$ Even sometimes the principle is influenced by socio-political conditions. In addition to the different terms in each country, the notion of public interest is also different in each country as it is influenced by the philosophy, political system, government, and characteristics of the nation. ${ }^{7}$

Public policy can be categorized into domestic and international public policy.

\footnotetext{
Ibid

6 Ayu Atika Dewi, 'Problematika Pelaksanaan Putusan Arbitrase Internasional di Indonesia' (2017) 2 (2), Jurnal Panorama Hukum, 193

7 Safrina, 'Peranan Pengadilan dalam Pelaksanaan Putusan Arbitrase Internasionall' (2011) 53 Kanun Jurnal Ilmu Hukum 144.

8 Susan Choi, 'Judicial Enforcement of Arbitration Awards Under the ICSID and New York Convention' (1996) New York University Journal of International Law and Politics 205.
}

Violation of domestic public policy means contrary to national laws and regulation or the national interest of the state concerned. ${ }^{8}$ Whereas in terms of international, public policy is violated if the violation touches the most basic nations of morality and justice. ${ }^{9}$

\section{National Legislations on Public Policy}

As stated above, in light of the of the 1958 New York Convention a court may refuse enforcement of an award on its own motion if the enforcement would be contrary to its country's public policy. In the absence of a definition of public policy in the Convention, most domestic courts seem in general, have difficulty in precisely defining the meaning and the scope of the notion. In the vast majority of jurisdictions, a violation of public policy implies a violation of fundamental or basic principles. ${ }^{10}$ These principles seem, however, to be differently expressed by courts (and scholars) depending on whether they are in civil or common law jurisdictions. In the first group, the definitions of public policy generally refer to the basic principles or values upon which the foundation of society rests, without precisely naming them. On the other hand in the second group, the definition often refers to more precisely identified, yet very broad, values, such as justice, fairness or morality. The Table 1 shows how states define and refer to public policy as the foundation of the legal system.

9 Wlliam Park, 'When the Borrower and the Banker are at the Oods, The Interaction of Judges and Arbitration in Trans-Border Finance, in Erman Rajagukguk, Implementation of the 1958 New York Convention in Several Asian Countries: The Refusal of Foreign Arbitral Awards Enforcement on the Grounds of Public Policy' (2008) 5(2) Indonesian Journal of International Law 189.

10 IBA Subcommittee on Recognition and Enforcement of Arbitral Awards, Report on the Public Policy Exemption in the New York Convention, October 2015, 6 
Table 1. Definitions of Public Policy

\begin{tabular}{|c|c|c|}
\hline No. & Countries & Definition Of Public Policy \\
\hline 1. & Belgium & $\begin{array}{l}\text { What touches upon the essential interests of the State or of the community } \\
\text { or sets, in private law, the legal basis on which rests the society's economic } \\
\text { or moral order }\end{array}$ \\
\hline 2. & Brazil & $\begin{array}{l}\text { The fundamental principles of its jurisdiction. It is worth mentioning that } \\
\text { public policy includes the political, legal, moral and economical aspects of } \\
\text { the constituted State }\end{array}$ \\
\hline 3. & China & $\begin{array}{l}\text { The principle of the law, fundamental interests of the society, safety of the } \\
\text { country, sovereignty and good social customs }\end{array}$ \\
\hline 4. & Egypt & $\begin{array}{l}\text { Rules aiming to achieve a public interest, whether political, social or } \\
\text { economic, pertaining to the society's high order and which prevails over the } \\
\text { individual interest }\end{array}$ \\
\hline 5. & Greece & $\begin{array}{l}\text { The fundamental statutory, moral, social, legal or economic perceptions that } \\
\text { prevail in the country }\end{array}$ \\
\hline 6. & Italy & $\begin{array}{l}\text { "Those fundamental norms and values of ethical, social, political and } \\
\text { economic nature that lie at the heart of the Italian legal order }\end{array}$ \\
\hline 7. & Portugal & $\begin{array}{l}\text { The State's most basic principles of social, ethical, political and economic } \\
\text { nature (inclusive of the ones comprised in the Constitution) }\end{array}$ \\
\hline 8. & Turkey & $\begin{array}{l}\text { The entire set of rules and institutions, which determines the foundation } \\
\text { structure and protects the fundamental interests of the society from the } \\
\text { political, social, economic, ethical and legal perspectives within a specific } \\
\text { period of time }\end{array}$ \\
\hline 9. & Australia & Fundamental norms of justice and fairness \\
\hline 10. & Canada & $\begin{array}{l}\text { The most basic and explicit principles of justice and fairness in Ontario" } \\
\text { and "the essential morality of Ontario." }\end{array}$ \\
\hline 11. & Singapore & The most basic notions of morality and justice." \\
\hline 12. & USA & $\begin{array}{l}\text { Most basic notions of morality and justice and fundamental notions of what } \\
\text { is just in the United States }\end{array}$ \\
\hline 13. & Indonesia & $\begin{array}{l}\text { (i) a violation of prevailing laws and regulations in Indonesia; (ii) a danger } \\
\text { to the national interest of Indonesia, including its economy and (iii) a } \\
\text { violation of the Indonesian sovereignty }\end{array}$ \\
\hline 14. & India & $\begin{array}{l}\text { "(i) fundamental policy of Indian law; or (ii) the interests of India; or (iii) } \\
\text { justice or morality }\end{array}$ \\
\hline 15. & Pakistan & $\begin{array}{l}\text { Community sense and common conscience extended and applied } \\
\text { throughout the State to matters of public morals, health, safety, welfare and } \\
\text { the like }\end{array}$ \\
\hline
\end{tabular}

Based on the table above, it can be seen that civil law countries (1-8) refer public policy as the foundation of the legal system on which is based on the moral, political and economic order of the society. In contrast, the definition is common law countries (9-12) tend to define public policy as norms of fundamental values, justice, and fairness. Whereas in a minority jurisdiction (13-15), public policy seems to be given a much broader content. Despite the differences, many courts stress that public policy remains a nebulous and evolving concept. ${ }^{11}$

\section{Public Policy by Case Law}

As the most popular reason for rejecting the enforcement of arbitral awards, public policy has been interpreted in a number of international legal cases. To this day, the concept has become the object of debate due to its controversial and complex weight. Since national courts of states have

11 Paul Stothard, Alexa Biscaro, 'Public Policy as a Bar to Enforcement, Where are We Now?' (2018) 10 International Arbitration Report 23. 
taken diverse approaches in solving the problem. These various approaches are presented in the Table 2.

Table 2. States' Approach

\begin{tabular}{cll}
\hline \multicolumn{1}{c}{ States } & \multicolumn{1}{c}{ Case } & \multicolumn{1}{c}{ Approach } \\
\hline USA & $\begin{array}{l}\text { American Construction } \\
\text { Machinery \& Equipment }\end{array}$ & The refusal to enforce award in light of the obligations \\
& $\begin{array}{l}\text { Corporation Ltd. } v . \\
\text { Mechanised Construction }\end{array}$ & policy. To read the public policy defense as a parochial \\
& device protective of national political interests would \\
& of Pakistan Ltd. ${ }^{12}$ & seriously undermine the Convention's utility. \\
Eco Swiss China Time & Public order means fundamental principles inside the \\
& Ltd. . Benetton & EU, including competition regulations. \\
& International $N V^{13}$ &
\end{tabular}

Through the decision of the abovementioned US court, it can be said that courts in America take a very restrictive approach in interpreting public policy. It is clear that any intervention in the national court in international arbitration regarding this matter must be minimized. The refusal of rejection of the enforcement of an arbitral award should be seen as an "exceptional circumstances".

On the other hand, French courts also take a restrictive approach, where the reason for public policy can be used when an award completely violates French public policies or fundamental principles. In the abovementioned case, competition regulations are considered as one of the fundamental principles recognized in the European Union. Hence, in this situation, a foreign arbitral award may be rejected on the grounds of violating public policy.

\section{Indonesian Laws and Regulations}

In general Indonesian laws contains the term public policy. For example in Law No.
9 year 2004 concerning the Administrative Court, public policy means the interest of the nations and state and/or the interest of the people and/or the interest of the development in accordance with the existing regulations. ${ }^{14}$ From this article, the term is exceedingly broad. Public policy is connected not only with the interest of the state but also with the people as well as national development. Furthermore, no laws explain what the interests of the state or nation is. However, when it comes to the issue of the interests of the state's development, of state's assets or money may be classified as falling within that meaning.

Related to arbitration, the provisions of public policy could be found in Presidential Decree No. 34 Year $1981,{ }^{15}$ as a ratifying legislation of the 1958 New York Convention. Indonesia has ratified the Convention which came into force on June 7, 1959. In connection with this, article 5 emphasizes that not all foreign arbitration decisions can be implemented. In other words, the enforcement of a foreign

12 American Construction Machinery \& Equipment Corporation Ltd. v. Mechanised Construction of Pakistan Ltd. case, 417 US 506, 1974

13 ECJ, Eco Swiss China Time Ltd. v. Benetton International NV, 1999

14 Explanatory to article 49 of the law. Article 49 says that the Administrative Court shall not have the

power to adjudicate and decide the disputes concerning the decisions made by the authorities where the decisions are made in the interest of public policy based on the applicable laws.

15 Presidential Decree No.34 Year 1981 on the Ratification of Convention on the Recognition and Enforcement of Foreign Arbitral Awards

54 | Saraswati - Discourse Interpretation of Public Policy in the Context of... 
arbitration award may be refused. One reason often used for such basis is regarding violations of the principle of public order in a country where the decision was made. The problem is that the Presidential Decree has only two articles, namely the article which states the binding on the Convention, as well as the entry into force article. There is no translation text of the New York Convention in Bahasa Indonesia. ${ }^{16}$

Responding to the New York Convention that had been codified, the Supreme Court issued Supreme Court Regulation No. 1 Year 1990 on the Procedures for Implementing Foreign Arbitration Decisions in accordance with the mandate of Article 3 of the New York Convention 1958. Public order is considered important, therefore the conditions must not conflict with public order which states: "obviously contrary to the joint human rights and the entire legal system and society in Indonesia". ${ }^{17}$

Furthermore, public order is further strengthened in the Law No. 30 Year 1999 concerning Arbitration Law and Alternative Dispute Resolution Law (hereinafter the Arbitration Law), which states that international arbitration decisions that can be implemented in Indonesia are limited only to decisions not in conflict with public order. ${ }^{18}$ This means if an international arbitration award is contrary to public order of Indonesia, then the executioner's application may be rejected. ${ }^{19}$

The existence of the above Indonesian national regulations does not guarantee the clarity of the meaning of public order. Hence,

16 At present all international agreements must be translated into Indonesian based on Law No. 24 of 2009 concerning Flag, Language and State's Coat of Arms and National Anthem

17 Supreme Court Regulation No. 1 Year 1990 on the Procedures For Implementing Foreign Arbitration Decisions, article 3 ( 3), restated in article 4 (2) this norm creates uncertainty for any parties. The main problem is that all of the legislation does not provide a clear definition to the term "public order". 20 There is no clarity regarding what public order is and whose public order will be violated if the decision is executed. This may create problems regarding what kind of interpretation will be used to define public order. Could the interpretation be narrow or broad? What are the limits? To what extent will the ranges be? It can be said that the enactment of the Arbitration Law is not in accordance with the principle of legislation contained in article 5 letter (f) of Law No. 12 Year 2011 on the Establishments of Laws and Regulations, specifically the principle of clarity of formulation, which must fulfill the requirements for using accountable and definite legal language preventing ambiguation in the interpretations.

When referring to doctrines, there are different interpretations of what public order is among experts. For example, some experts formulate public order as a provision of main principles of law and national interests of a nation. However, once again in practice the explanation is still interpreted extensively due to unclear boundaries and arrangements. Thus, this does not fulfill the most basic legal principles, the principle of legal certainty. Therefore, public justice and benefits as noble ideals of law enforcement are yet to achieve.

In connection with interpretation, Sudargo Gautama argued that it should not be contrary to public order, requiring that carrying out foreign arbitration decisions in

18 Law No. 30 Year 1999 concerning Arbitration Law and Alternative Dispute Resolution Law, article 66 (e)

19 Gunawan Widjaja dan Ahmad Yani, Hukum Arbitrase, (Raja Grafindo Persada, 2001), 134.

20 Jan Paulsson, The Idea of Arbitration (Oxford Up, 2013), 200. 
the Republic of Indonesia would create a great shock in the legal system in Indonesia. Public interests include the joints and fundamental values and national interests of a nation. ${ }^{21}$ The contents of the foreign decision are manifestly incompatible, as stated in the conventions of private international law. This means that the foreign arbitral awards that request a distinguish implementation are strikingly unacceptable to the Indonesian legal system, for it contradicts the 1945 Constitution and Pancasila, as well as other fundamental principles. However, the restriction should be used as efficiently as possible, working as a shield in case only to keep the Indonesian legal system from experiencing a great shock, and not as a sword. ${ }^{22}$

Yahya Harahap, a former Chief Justice and Arbitration expert, provides the following limits on the principle of public order: "a matter which is considered contrary to order in an environment (state) if it contains a matter or condition that is contrary to the principles and values of the system law and national interest of a nation". ${ }^{23}$

Whereas Erman Rajagukuguk turned to the public interest as order, welfare, and security (law order or justice). ${ }^{24}$ Meanwhile, Tony Budidjaja suggested that violations of public order should be considered as a violation that exceeded or weighed more than

21 Sudargo Gautama, Undang-Undang Arbitrase Baru 1999 (Citra Aditya Bakti) 2.

22 Tineke Tuegeh Longdong, Asas Ketertiban Umum dan Konvensi New York 1958 (Bandung, P.Citra Aditya Bakti, 1998) 152.

23 Decision of Cassation of the Supreme Court of the Republic of Indonesia No. 01 K / Pdt.Sus / 2010 case between Astro Nusantara International BV, Astro Nusantara Holding BV, Astro Multi Media Corporation NV, Astro Multimedia NV, Astro Overseas Limited, Astro All Asia Network PLC, Measat Broadcast Network System SDN BHD and the reasons contained in article 70 of the Arbitration Act. ${ }^{25}$

Furthermore, according to article 23 Algemene Bepalingen van Wetgeving voor Nederlands Indië (hereinafter “AB”) which is the General Legislative Provisions for the Dutch East Indies, State Gazette 1847 No.23, public order is a violation of moral rules. The provisions of article $23 \mathrm{AB}$ are not only limited to the national atmosphere but also include the international atmosphere, because it covers all agreements as well as other legal actions that occur within the territory of the national state. Dr. Tin Zuraida, SH, M.Kn in her book, The Principles for Executing International Arbitration Awards in Indonesia, Theory and Practice, cited Prof. Mr. Sudargo Gautama that the so-called Public Policy or public order is as follows: "public policy or openbare orde is just " $a$ reserve principle which is only to be invoked exceptionally".

The above explanation illustrates how public order is very relative, which makes judge interpret the concept differently.

\section{Judge's Interpretation of Public Policy}

As said before, Indonesian Arbitration Law provides that an international award can only be enforced in Indonesia if not contrary to public policy. However, public policy is not clearly defined in a number of Indonesian legislation providing no uniform judicial approach to the interpretation and application.

All Asia Multimedia Network FZLLC against PT. Ayunda Primatamitra, PT. First Media, Tbk and PT. Direct Vision, 20

24 Erman Rajagukguk, 'Hukum Ekonomi Indonesia: Menjaga Persatuan Bangsa, Memulihkan Ekonomi, dan Memperluas Kesejahteraan Sosial' (2003) 5 Jurnal Hukum Bisnis 22.

25 Suleman Batubara, Orinton Purba, Arbitrase Internasional Penyelesaian Sengketa Investasi Asing Melalui ICSID, UNCITRAL dan SIAC (Penebar Swadaya Grup, 2013), 151.

56 | Saraswati - Discourse Interpretation of Public Policy in the Context of... 
There is no further guideline on the application of the principle of public policy in relation to the recognition and enforcement of international awards. ${ }^{26}$ In practice, the reasoning of court decisions that refuse enforcement on the basis of public policy varies, and should be analyzed on a case-bycase basis.

Table 3. Public Policy Interpretation

\begin{tabular}{|c|c|c|}
\hline No. & Case & Public Policy Interpretation \\
\hline 1. & $\begin{array}{l}\text { ED \& F Man (sugar) Ltd v } \\
\text { Haryanto }^{27}\end{array}$ & $\begin{array}{l}\text { The unlawful agreements which violate the mandatory rules and regulations in } \\
\text { Indonesia relevant to the subject matter of the agreements are seen as a violation } \\
\text { of public policy. The agreement violated the prevailing laws in Indonesia which } \\
\text { regulated that imports of sugar were the sole discretion of BULOG. }\end{array}$ \\
\hline 2. & $\begin{array}{l}\text { Bankers Trust v PT Mayora } \\
\text { Indah TBK }(2000)^{28}\end{array}$ & $\begin{array}{l}\text { A contradictory ruling of the Indonesian court that had not gone through the full } \\
\text { judicial appeal process as well as the granting of an exequatur would only } \\
\text { confuse and be against Indonesian public policy. The enforcement of the foreign } \\
\text { arbitral award would amount to a violation of Indonesian public policy because } \\
\text { the same matter is currently being examined by an Indonesian court which has } \\
\text { not rendered its decision yet. }\end{array}$ \\
\hline 3. & $\begin{array}{l}\text { The Astro Nusantara Bv et } \\
\text { al v PT Ayunda } \\
\text { Primamitra 2010) }\end{array}$ & $\begin{array}{l}\text { The arbitral award, which contained an order to cease the on-going legal } \\
\text { proceedings in Indonesia violated the sovereignty of the state because no } \\
\text { foreign power could ever interfere with the on-going legal proceedings in } \\
\text { Indonesia. Violation of state sovereignty is against Indonesian public policy. }\end{array}$ \\
\hline 4. & $\begin{array}{l}\text { PT Bakri Brothers v. } \\
\text { Trading Corporation of } \\
\text { Pakistan Ltd }(1984)^{30}\end{array}$ & $\begin{array}{l}\text { Due process, which means public policy as a fundamental principle, includes } \\
\text { that all parties have an equal opportunity to be heard. This principle demands } \\
\text { that each party must have been effectivity offered such opportunity. The } \\
\text { proceeding failed to provide equal treatment therefore considered a violation of } \\
\text { public policy. }\end{array}$ \\
\hline
\end{tabular}

The principle in international law is what has been legally recognized in a national law in terms of arbitration must also be recognized in other countries. This public policy should be interpreted strictly and applied carefully. This principle is only an exception. No agreement in international law should fail to develop and lose to national law.

Based on the table above, Indonesian courts have interpreted the public policy exception very broadly where is applies

26 Ade Maman Suherman, Arbitrase dan Alternatif Penyelesaian Sengketa, Aspek Hukum Dalam Ekonomi Global (Ghalia Indonesia, 2014), 39.

27 The Central Jakarta District Court Decision No. 499/Pdt/G/VI/1988/PN.Jkt.Pst dated 29 June 1989, upheld by the Jakarta High Court Decision No. 486/Pdt/1989/PT.DKI dated 14 October 1989, and subsequently by the Indonesian Supreme Court Decision No. 1205 K/Pdt/1990 dated 14 December 1991.

28 The CJDC Decisions No. 01 and 02/Pdt/Arb.Int/1999/PN.Jkt.Pst in conjunction with No. 02/Pdt.P/2000/PN.Jkt.Pst dated 3 February 2000, upheld by the Indonesian Supreme Court Decision No. $02 \mathrm{~K} / \mathrm{Ex}$ ’r/Arb.Int/Pdt/2000 dated 5 September 2000, in conjunction with the public policy in the "domestic" sense. This bearing is due to the provision of Article 4 (2) of the Supreme Court Regulation Number 1 of 1990 on the Enforcement Procedures of Foreign Arbitral Award mentioned earlier. From such provision, the emphasis of public policy is laid on the Indonesia's internal conditions, such as, ${ }^{31}$ a violation of the prevailing laws and regulations in Indonesia; endangering the national interest of Indonesia; and a violation against the

SJDC Decision No. 46/Pdt.G/1999/PN.Jkt.Sel 9 December 1999.

29 The CJDC Decision No. 05/Pdt.Arb.Int/2009 dated 28 October 2009, upheld by the Indonesian Supreme Court Decision No. 01 K/Pdt.Sus/2010 dated 24 February 2010.

30 The South Jakarta District Court Decision No. 64/Pdt/G/ 1984/PN.Jkt.Sel dated 1 November 1984, upheld by the Jakarta High Court Decision No. 512/Pdt/1985/PT.DKI dated 23 December 1985, and subsequently by the Indonesian Supreme Court Decision No. 4231 K/Pdt/1986 dated 4 May 1988.

31 Frans H. Winarta, Indonesia Country Report on Public Policy for IBA APAG (IBA, 2015), 
sovereignty of Indonesia, and not on international conditions. ${ }^{32}$

In sum, the examples show that specific reasons are the basis for saying that a foreign arbitration decision is contrary to the public policy in Indonesia, namely:

a. If during the process of legal proceeding a party is not given the opportunity to be heard enough before the decision is taken, this is considered as a form of intervention towards the on-going proceeding of the domestic courts.

b. If the procedure for taking the arbitral award is not in accordance with the procedural law, the verdict is taken in violation of the arbitration law agreed upon by the parties. In this case there was a district court that was still hearing and examining the case of the two parties. This definitely violates public policy.

Under the international standard, the violation of public policy is viewed as an attitude which sets aside the value of the state and also the norms and rules under its restrictive international obligations. ${ }^{33}$ It is why merely adopting the ground of contravention of the state's internal rules of law, including its mandatory rules, is not considered as legal justification for refusing enforcement of foreign arbitral awards. ${ }^{34}$ Therefore, the stance taken by the Indonesian courts have been criticized as exaggerating and out of the principle of fundamentality, which has been discerned to be not enough

32 Erman Rajagukguk, Implementation of the 1958 New York Convention in Several Asian Countries: The Refusal of Foreign Arbitral Awards Enforcement on the Grounds of Public Policy, Paper Presented in the 3rd Asian Law Institute (ASLI) Annual Conference on The Development of Law in Asia: Convergence versus Divergence?, Shanghai May 25-26, 2006, 2. reasonable for objecting the international nature of arbitral awards. This adoption of broad and "domestic" public policy exception has made it difficult for a winning party to enforce foreign arbitral awards.

\section{CONCLUSIONS AND SUGGESTIONS}

Although Indonesia has ratified New York Convention, Indonesia has shown several unfriendly approaches to foreign arbitration through rejection of the enforcement of foreign arbitral awards. Through several case law, it is found that the Indonesian judicial attitude towards public policy defense to refuse enforcement of foreign arbitral awards has been broad and expansive. The decisions that have been made by the court give rise to various criticisms on the grounds of using a "domestic" perspective, and not a perspective based on values and principles of international law.

Such conditions are seen by the international community as a legal uncertainty. Therefore, in term of normative aspect, the law in Indonesia needs to expressly draw the distinction between international and domestic public policy. In terms of interpretation by the courts, Indonesia need to see and compare best practices by other states. This is to prevent courts to easily intervene in the enforcement of international arbitration award on the grounds of public policy.

33 International Law Association, Resolution of the ILA on Public Policy as Bar to Enforcement of International Arbitral Awards (ILA, 2002)

34 Mahmudin Nur Al-Gozaly, 'The Judicial Expansive Attitude towards Public Policy in Enforcement of Foreign Arbitral Awards in Indonesia', (2014) 14 Jurnal Opinio Juris 162. 


\section{REFERENCES}

Books

Batubara, Suleman, and Purba, Orinton, Arbitrase Internasional Penyelesaian Sengketa Investasi Asing Melalui ICSID, UNCITRAL dan SIAC (Penebar Swadaya Grup, 2013).

Gautama, Sudargo, Hukum Perdata Internasional Indonesia Buku IV, (Alumni, Bandung, 1989).

Gautama, Sudargo, Undang-Undang Arbitrase Baru 1999, (Citra Aditya Bakti).

Paulsson, Jan, the Idea of Arbitration, (Oxford Up, 2013).

Widjaja, Gunawan and Yani, Ahmad, Hukum Arbitrase, (Raja Grafindo Persada, 2001).

\section{Journals}

Al-Gozaly, Mahmudin Nur, 'The Judicial Expansive Attitude towards Public Policy in Enforcement of Foreign Arbitral Awards in Indonesia' (2014) 14 Jurnal Opinio Juris.

Choi, Susan, 'Judicial Enforcement of Arbitration Awards Under the ICSID and New York Convention' (1996) New York University Journal of International Law and Politics.

Chong, Adeline, 'Transnational public policy in civil and commercial matters', (2012) Law Quarterly Review.

Dewi, Ayu Atika, 'Problematika Pelaksanaan Putusan Arbitrase Internasional di Indonesia' (2017) 2(2) Jurnal Panorama Hukum.
Hikmah, Mutiara, 'Penolakan Putusan Arbitrase Internasional dalam Kasus Astro All Asia Netwok Plc, Kajian Putusan Nomor 05/Pdt/ArbInt/2009/PNJP', (2012) 5(1) Jurnal Yudisial.

International Law Association, 'Resolution of the ILA on Public Policy as Bar to Enforcement of International Arbitral Awards 2002'

Longdong, Tineke Tuegeh, Asas Ketertiban Umum dan Konvensi New York 1958, Bandung: P Citra Aditya Bakti, (1998) Rajagukguk, Erman, 'Hukum Ekonomi Indonesia: Menjaga Persatuan Bangsa, Memulihkan Ekonomi, dan Memperluas Kesejahteraan Sosial', (2003) 5 Jurnal Hukum Bisnis.

Safrina, Peranan Pengadilan dalam Pelaksanaan Putusan Arbitrase Internasional, (2011) 53 Kanun Jurnal Ilmu Hukum.

Stothard, Paul, Alexa Biscaro, 'Public Policy as a Bar to Enforcement, Where are We Now?' (2018) 10 International Arbitration Report.

\section{Laws}

Convention of the Recognition and Enforcement of Foreign Arbitral Awards, 1958

Presidential Decree No.34 Year 1981 on the Ratification of Convention on the Recognition and Enforcement of Foreign Arbitral Awards

Law No. 30 Year 1999 concerning Arbitration Law and Alternative Dispute Resolution Law 